\title{
AFTER THE BATTLE OF PLEASANT HILL, LA.
}

\section{BY CAPT. MICHAEL ACKERMAN.}

On the evening of April 8, 1864, at the cemetery of Pleasant Hill, several officers were standing together, discussing the events of the day. The Seventeenth corps had been defeated and retreated into our lines demoralized and badly used up. The officers talking over the situation were Lieut. Col. Edward U. Mix, Capt. Amos B. Miller of Company B, Capt. Hubert F. Peebles of Company C, Lieut. Thomas O. Howard of Company B, myself and others. Colonel Mix looked up and said: "There, I see the moon over my right shoulder. According to the old saying it is a good omen and I need not worry." Of these officers just twenty-four hours later, Colonel Mix was dead, Captain Miller, Captain Peebles and Lieutenant Howard were mortally wounded and I was left on the field for dead with two severe wounds,--one bullet through my left knee and another through my right hip. How we formed in line of battle on April 9th; how we stood our ground until nearly half of the regiment was wiped out; how Company $A$ went into battle with thirty-four men in line and only five answered to roll call next morning, I need not tell. You have that in history.

I fell about sundown, and only a few minutes after was stripped by the Confederates of everything except my pants, shirt and underclothing. I had eighty-five dollars in the right pocket of my pants which belonged to the heirs of John Basham who had died in the hospital. One of the Confederates put his hand in my pocket and would have robbed me of that money. The pocket was full of blood from the wound in my hip, and that proved too much even for him. With an oath he withdrew his hand and left me the eighty-five dollars. Money never did me as much good as that did, as you will see later on. They took my watch which had been hit by a ball, 
the works destroyed and its value as a timekeeper lost. But one of them said, "The case will make good stars or bars." I remarked that such men as he never would have use for stars or bars. I expected they would finish me and at that time I did not expect to see another sunrise. They stripped Colonel Mix and others stark naked.

About that time the rebels struck our second line. Did you ever take shelter in a hail storm under a board roof? If you did, you can form some idea of the rattling of musketry and the striking of balls around us. I think I got scared for the first time that day. When I was shot I fell beside a ditch about four feet deep, five feet wide and with two inches of water in it. I now rolled into this ditch to be out of the way of our own bullets. Was it not strange? Here I was, not expecting to live, and yet rolled into the ditch for fear of being hit by any more balls.

I describe this ditch more particularly because it is the grave of many of our brave boys of the Thirty-second. It is the grave of Colonel Mix and such men as fell dead around there. I learned afterwards that they were tumbled into this ditch indiscriminately, rebels and Union men, and a little dirt thrown over them.

About twelve o'clock, as near as I could judge, I got very cold, and hearing some one talking and walking near me, 1 asked him to help me out of the ditch. He was a rebel chaplain and very small, but his heart was as big as an ox. He tried, but could not lift me, so I told him to raise up my legs and I would crawl out. This we managed. Somebody had built a fire. I got beside it and was soon asleep. When I waked up the sun was high up and the boys had put a shelter (part of a dog tent) over me to keep off the sun. John Talbut of my company came to talk to me but I could not understand what he said. A minie ball had entered his mouth, cut off his tongue and passed out through the neck. The poor boy only lived about nine days.

Looking around the place where but twenty-four hours ago we had been standing in all the strength of our manhood, I saw the ground strewn with the dead and wounded so that a 
person might go as far as I could see on the bodies of the dead and wounded without once stepping on the bare ground. Here and there a group of wounded gathered around a little fire.

About nine o'clock that evening Captain Miller and myself were put in an ambulance and taken about a mile or a mile and a half to a $\log$ house and laid on a blanket on the floor. There were from six to ten others there. One was Robert Mack of my company. He was wounded in the shoulder and the ball had lodged under and at the edge of his shoulder blade. He came to me with an old, dull jackknife and wanted me to cut the ball out. I tried, but the knife was too dull. He went and sharpened it on a cobblestone and came back, but I could not do it as my nerves were not in a fit condition. He persuaded some one else to do the butchering and lived and got well.

The next day, April 11th, we were very hungry. None of us had had anything to eat since before the battle. Captain Miller said if I would reach under his head I would find some hard-tack which he had there and we might eat some. There were four and we each ate one. That night Captain Miller died. He had been shot through the bowels, and although he knew he could not live, he was cheerful to the last minute. He did not give me any keepsake or word to carry home for neith'er he nor I expected I would ever get there.

I stayed in this $\log$ house four days without seeing a surgeon or having anything to eat except the two hard-tack Captain Miller had left me. You would naturally ask why, when there were seven doctors detailed and left there from our own army, there should be none to attend to us. We were left there by a blunder. There were two places used for hospitals and the surgeons were there and had all they could do.

After being in this house four days I was removed to the new academy now used as a hospital, and laid on the same blanket with Captain Peebles of Company C. He had been shot through the knee and his leg was already cut off. The doctors said he was doing very well and if his constitution held out he would get well. He was cheerful and in good spirits, 
but his constitution was not strong. Lieutenant Howard I never saw. He had died before this.

About this time I had my first experience with prison fare. Some one brought me a dish of,--I don't know what you would call it. It was musty cornmeal, unsifted, mixed with water and just about warmed through, with a lump of bloody beef in it. I said, "Boys, you have not half cooked this." They answered that they had done the best they could; that there were over three hundred of us and only three kettles to cook with. Is it any wonder that so many died there? It was not all wounds that killed them. I don't blame the rebels any on that score. That was all they had. After some of our men were taken to Tyler, Texas, and many more died, they had a better way of preparing their meals and our cooking was better.

I don't know how long it was, but it must have been some eight or ten days after I was put with Captain Peebles that I woke up one night and he was singing and praying and tearing away at his wound. I reached down and found his limb bleeding. I called the doctor, but it was too late. He had torn off the bandage and the flesh from his stump and lost so much blood that he died before morning.

My back got so sore lying on the hard floor with nothing but a blanket under me, that the bare backbone stuck out and bothered me more than either of my wounds, so they put me on a cot. The maggots troubled us a good deal, but I will leave what $I$ saw and felt about that untold and tell something more pleasing.

A lady by the name of Cole came to this hospital once and sometimes twice a week with a one horse light wagon loaded with chicken broth, pies and other good things to eat. She distributed these to the most needy of us and never would take anything for it. Her husband was an officer in the rebel army. She was about forty years old. Her image is deeply impressed upon our hearts and will never be dimmed or erased. If ever a woman deserved the gratitude of a nation, Mrs. Cole is entitled to it. Several times I saw her when some of the boys came to her and asked for something to eat, tell them with tears running down her cheeks that it was all gone but that she would go and get what she could and bring 
it in. May God bless her evermore. A few years ago I wrote to the postmaster at Pleasant Hill, inquiring about her, but he could give me no information.

There is one other thing I must not forget. I cannot give the time, but it must have been some five or six weeks after we were taken prisoner that one day two army wagons loaded with sanitary goods came with a flag of truce. Think of our joy, not only for the goods that these wagons contained, but in the thought that our friends, possibly our near relatives, thousands of miles away had thought of us, prisoners of war, wounded and sick, and had sent to us with their blessing delicacies their hands had prepared. I have often heard during and since the war that most of the sanitary goods were squandered and that those that deserved them never received any, but we received our share. Out of the tens of thousands of sick and wounded in the United States army, we, only a handful of about sixty or seventy, received two big wagon loads. Every one of the boys who were there at that time will say with me to those ladies who worked so hard and steadfastly that they did not work in vain and that they have our heartfelt thanks and gratitude.

With the money I had in my pocket when I was wounded, which the rebels tried to take and didn't, I bought eggs, chickens and tobacco. I paid one dollar per dozen for eggs, one dollar for a fried chicken and four dollars per pound for tobacco. I got about two eggs out of a dozen and about a shank and wing out of a chicken and about the same proportion of the tobacco. But how could it be otherwise? The boys had no money, over four months' pay was due us and no prospect of getting any very soon. Maybe you don't know how it seems to be eating something good and a lot of halfstarved, wounded and sick boys looking on. Well, one or two dozen eggs and.one or two chickens did not last long. Tobacco, as now, was always free. When the money was almost half gone I did better. I traded U. S. money for Confederate money, one dollar for five, and their money bought the same as ours.

As time wore on some one would come in to tell me that such and such a one died last night, or this morning, and 
that such and such a one was not expected to live. This went on until about the 17th of June when a rebel officer came with our paroles. Here was a dilemma. We were seventeen miles from the boat landing. Of the fifty-three of us that had survived some could walk but the most of us had to go in wagons. Ambulances there were none, nor a spring wagon in that part of the country, so there was nothing left but the army wagon. It was decided by the surgeons that a comrade and myself could not be moved. Dr. Wm. L. Huston, Assistant Surgeon of the Thirty-second Iowa Infantry, told me with tears in his eyes that they would have to leave me. I begged him to take me but he said it would be of no use; I would die on the road. I implored him with all the eloquence in my power; promised him I would not. die, or if I did, it would not be his fault. Told him to throw me out and go on. It would not be worse than if I were left alone and I would surely die if left.

Finally he promised he would see what he could do. Poor Doctor! he had no more idea of taking me there alive than he harl of flying. In a little while he returned and said he had procured a conveyance, such as it was. I can see it yet,an old sorrel horse and an old shackly wagon without springs, but it corresponded with the passenger for I was in a very dilapidated condition.

After I was loaded in, the Doctor gave me a canteen full of Louisiana rum and told me to drink it and have the canteen empty before we got to the river. He told me whenever I felt pain to let him know and he would give me opium. We started with the Doctor driving. All along the road the boys would pick blackberries and give me a tin cup full with milk. I don't know where they got the milk, but guess they had not forgotten how to forage. When we reached the river my canteen' was empty and the Doctor said he had given me fourteen grains of opium going the seventeen miles. I did not feel the liquor any more than so much water. I felt happy and without pain on that whole trip.

Fifty-two of us started from Pleasant Hill that fine June morning, and fifty-two arrived in New Orleans, I don't know how soon after, but it did not seem long to me. 
I will have to relate an incident that happened on this trip down Red River. George A. Demander of Company $F$ had received a shot in the eye ( $I$ think, the left). The ball passed in at the eye and passed out back of his ear and caused him to be partially out of his head. There was also a lieutenant of a New York regiment on board. The boys said that when his regiment was going into line of battle this lieutenant made a misstep and sprained his ankle, and fell behind or under a fence. Anyway, the rebels captured him and he was not wounded or hurt. On the boat he ordered George to get him some water to wash in, George would not do it, so he gave George a lick on the head and knocked him down. This happened on the hurricane deck. The Doctor in charge of us, a big stout fellow, grabbed the lieutenant, and from there down to the foot of the stairs it looked to me as if the Doctor had a dozen legs, every leg had a foot and every foot struck this lieutenant on that part of his breeches that he was in the habit of sitting on. When they' got downstairs the lieutenant said to the Doctor, "I'll make it hot for you when we get into our lines." The Doctor told him to go to $\mathrm{h}-\mathrm{l}$; he'd teach him not to meddle with any of his patients. How the boys cheered!

We arrived in New Orleans in due time, a happy lot of half-starved and crippled soldiers, our fighting days over. While here I had a craving for something sour and sent one of the waiters to get me some pickled pigs' feet. I ate one, and wasn't I sick! I parted with every particle of cornmeal and blue beef I had eaten for the last nine weeks while in the rebel prison. They called for the Doctor and he was mad. He wanted to know who gave me those pickles; he would have him courtmartialled. But he never found out. I told him that was my business; I had sent for them myself and paid for them.

Well, this is about all! We stayed in New Orleans three days, then were sent to Memphis, from there to St. Louis and finally home. This is a short history of our army wanderings after the battle of Pleasant Hill. 
Copyright of Annals of Iowa is the property of State of Iowa, by \& through the State Historical Society of Iowa and its content may not be copied or emailed to multiple sites or posted to a listserv without the copyright holder's express written permission. However, users may print, download, or email articles for individual use. 